\title{
The Impact of Fee and Liability Waivers on Patronage of Rattray Park in Ghana
}

\author{
Seth Koli \\ Department of Ecotourism and Environmental Management \\ University for Development Studies, Ghana \\ Conrad-J. Wuleka Kuuder \\ (Corresponding Author) \\ Department of Ecotourism and Environmental Management \\ University for Development Studies, Ghana \\ kwuleka@uds.edu.gh \\ Getrude Poku \\ Department of Ecotourism and Environmental Management \\ University for Development Studies, Ghana \\ DOI//http://dx.doi.org/10.4314/gjds.v17i2.3
}

\begin{abstract}
The study assessed the relationship between fee and liability waivers introduced at Rattray Park vis-a-vis its patronage by low income earners within the Kumasi Metropolis. Barriers to park use as well as safety awareness were also analysed. The research design adopted as a guide was the survey study method. In all, 141 revellers were contacted through questionnaire administration within a 3-day period during the programme. Indepth Interview (IDI) schedules were also conducted with key stakeholders who were incharge of organising the waiver programmes. Quantitative data were analyzed using SPSS while qualitative data were manually transcribed. The study revealed that low income earners took advantage of the waiver programmes (attested by $44 \%$ of respondents) with p-value of 0.034 to make use of the park. Similarly, about $70 \%$ of respondents considered inability to afford the cost of entry tickets a factor which hindered their recreational use of the park. The fee waiver concept was noted in the study as well-intended and a strategic recommendation suggested by park-goers signaled the need for boosting recreational activities in the park to engage visitors all day long for a richer experience.
\end{abstract}


Keywords: Fee Waivers, Liability Waivers, Revellers, Rattray Park, Low Income Earners

\section{INTRODUCTION}

Globally cities have undergone profound reforms in recent decades, as politicians, decision makers and planners have often sought to ensure that the built and natural environment remains liveable and can adapt to new lifestyles and demographic trends (Makufwe, 2014). Parks which are a part of both the natural and built environments have been touted to provide a variety of benefits to humans around the world notably: personal, economic, social and psychological (Sibeko, 2007). A park thus, is an open space provided for recreational use, usually owned and maintained by local government (Daniels \& Schur, 2015) whilst acknowledging that there are parks that are privately owned. Examples of parks aligned to governments and providing such services include; la Alameda de Hercules (opened in 1574) in Seville (Southern Spain). Yellowstone National Park (1872) opened in the United States of America, and enacted by an act by the 42 nd Congress of the USA gave birth to the world's first ever declared national park (National Park Service, 2018). Mention is made in the literature of the Northeast Greenland National Park (1974) purported to be the largest land national park in the world (Safaris Africana, 2018). Indeed, the strength of a community or city is increased through recreation activities that allows people of varied cosmopolitan backgrounds to meet and intermingle with its associated advantage of eliminating loneliness and conquering boredom. Park related activities are therefore noted to enhance the quality of life and thus improve mental health (Department of Leisure, Family and Recreation, Manchester Recreation Division, 2020).

Africa as a continent has spectacular recreational parks of great repute serving the physiological needs of people. Some renowned recreational parks within the continent are uShaka Marine World and Oasiria in South Africa which offer great scenes in sea world, kids' world and village walks. Noted within are fascinating scenes of false water cobras, anaconda photo taking opportunity and other weird scenes. In this regard, mention is also made of Oakland Park and Dream World (also known as Dreamworld Africana) in Nigeria with amusements such as wet and dry facilities, bumper cars, carousal, roller coaster, trains, merry go-rounds and toddler play areas. Ghana as a nation has in recent decades enjoyed the diverse benefits of such amusement facilities like Recreational Quadrangle, Lakeside Marine Park and the most recent one, Rattray Park, built and opened in June 2015 in Kumasi. 
There are important disparities in leisure-time physical activity by race/ethnicity and socio-economic position (Hendee, 1969). Although all societies are economically stratified, they differ markedly in their degree of inequality. Small agrarian and foraging societies are relatively equal, while larger industrial and post-industrial societies are characterised by large disparities in wealth and power (Massey, 2007). It is in the light of such inequalities for the purposes of recreation that waiver programmes are introduced so that those at an economic disadvantage can also seize an opportunity to use these same park facilities (otherwise thought to be meant for use by the rich) for their own recreation needs. A waiver is explained as voluntary relinquishment or surrender of some known rights and privileges (Denise, Evans \& William, 2007), examples being fee waivers and liability waivers. A liability waiver is a legal document that a person who participates in an activity may sign to acknowledge the risk involved in his/her participation. Fee waiver on the other hand is, the granting of a concession to some participants to enjoy a park facility without having to incur any cost (Siler, 2011).

In theory, public parks and recreational amenities are available to all regardless of their socio-economic status. Early public parks and recreation activity leaders sought to programme facilities and make them accessible to the masses concentrated in low-income communities including those living in the periphery of major towns (Scott, 2013). Proponents of early park and recreation believed that cities should provide park and recreation services for the economically disadvantaged groups. Indeed, from the 1900 to 1930, a major goal among many public park and recreation providers was to establish parks or extend existing park and recreation facilities to neighbourhoods with high concentration of people bearing in mind the needs of those with low income (Chubb \& Chubb, 1981). Even in recent times, there is a general belief among park and recreation professionals that people with low income have a greater need for government park and recreation services, yet efforts to reach the needs of the poor have been greatly compromised in recent decades as park and recreation agencies have become more business-oriented and profit minded in order to deal with rising cost of providing basic services (Massey, 2007). Massey (2007) noted that the problem of the poor and even some disabled, nevertheless, remain acute and will require creative solutions if they are to be solved. Such people tended to benefit less from physical activity and recreation policy interventions by government (Scott, 1997). It therefore stands to reason that there is a great backlog that exist in the provision and accessibility of recreation facilities in previously disadvantaged areas and therefore calling for an urgent need to address these imbalances and injustices of the past. 
It is also a common practice for waivers to be introduced in some recreational parks for students who take up internships and other research that are related to a course of study in their institutions. A case in point is the Grand Canyon (Arizona) which has opportunities for application for a fee waiver for educational study if the applicant is providing educational credit hours based on specific course of instruction and as such must provide an institutional accreditation letter before the intern is accepted (National Park Service, 2018).

It has consequently become pertinent to undertake this study which recognises the need for provision of waiver programmes for sections of society. Very often, the recreation needs of low income earners have always been neglected by city planners and those in authority. Most modern park recreation facilities are 'created' with the elite in mind who are able to afford and utilise such opportunities to engage in recreation. This paper therefore intends to fill the gap whereby studies fail to draw the attention of park and city authorities including service providers on the need for providing recreation services especially for the youth and those urban dwellers on "meagre incomes". Further to the aforementioned is the fact that there are also those who may not even be earning any form of income at all and who very often do not have the desired financial capacity particularly in the developing world to enable them engage in park (public) recreation. The contribution of this paper therefore lies in its attempt to draw city authorities' attention to the fact that the emphasis placed on profit making alone in recreational parks is inappropriate. Profiteering motives by city councils and park authorities must be watered down with much emphasis laid on the need to periodically avail waiver programmes to enable low income earners make use of the calibre of present-day ultra-modern park facilities provided now for their own recreational needs. The general aim of this study thus, is to assess the relationship between introduction of waiver programmes and public patronage of Rattray Park in Kumasi while the specific objectives sought to; ascertain the basis for which waiver programmes were introduced by stakeholders of the park, explore visitor perception on barriers to use of the park, assess extent of patronage of the park when waivers are introduced and evaluate safety awareness levels in the facility from the visitors' perspective especially when waivers are introduced.

The introduction of waivers, challenges to park facility use by the poor, patronage of park facilities during waivers and safety related issues at tourism recreational facilities are relevant themes used by the authors in this article. 


\section{Introduction of Waivers in Parks}

Facility fees charged for the use of city parks may be waived by the city authorities, in certain limited cases. The Recreation Programme Fee Waiver policy has been established to provide guidelines necessary to allow the youth and families in cities, the opportunity to participate in recreation programmes offered by parks and recreation authorities, regardless of their financial status. Persons who meet the guidelines for free usage will receive a full or partial fee waiver while it is usually reviewed on an individual or case by case basis. A liability waiver is a legal document stipulating that a person who participates in an activity may sign to acknowledge the risk involved in his/her participation. The waiver can be written or oral. A written waiver is a disclaimer which when accepted becomes a waiver. A liability waiver can also be referred to as accident waiver or indemnity clause or agreement exonerating the park or business entity from blame in case of accident. In Africa, especially in Alexandria, (Egypt) liability waivers have often become controversial issue due to conflicting information about their implementation in parks (Henderson, 1997; Younger, 2008; Siler, 2011; Daniels \& Schur, 2015; Berk \& Moon, 2016).

\section{Challenges to Park Recreation Use by the Poor}

In theory, public park and recreation amenities are available to all people regardless of their socio-economic status. Although Public Park and recreation leaders sought to make facilities and programmes accessible to people living in low-income communities, Public Park and recreation providers have struggled historically to meet the leisure needs of people who are disadvantaged economically. Challenges of recreation service provision are worsened by the fact that economic inequality among Africans for instance is on the rise with increasing incidence of urban poverty. A mechanism described as opportunity hoarding refers to situations where powerful groups take charge of scarce resources and limit weaker groups from accessing these resources through fees, rents, and prohibitions. Economic wellbeing similarly shapes people's access to a wide range of leisure amenities as the poor do not have access to recreation rooms, landscaped backyards, automobiles, recreation vehicles, seasonal homes, and other amenities that enhance recreation environments. In South Africa, challenges to residential public park use in the city of Bloemfontein have been noted to include lack of paved pathways and poor illumination in the evenings. Back home in Ghana, the reality is that poorer Ghanaians since time immemorial faced formidable barriers and constraints in accessing public and private recreation related amenities (Weber, 1978; Chubb \& 
Chubb, 1981; Fishkin 1983; Tilly, 1999; Scott, 2013; Makufwe, 2014; Das \& Honiball, 2016).

Further research has been conducted and the observation is that publicly funded leisure programmes and facilities are already available to all, but efforts to provide programmes and services to people with low income are futile and financially unreliable. In the light of the above, it has been noted that academics and researchers needed to work collaboratively with poorer communities to highlight the recreation needs of marginalised populations (Henderson, 1997; Cranz, 1982; Lathrop Parks and Recreation, 2015). Over the past couple of years, several innovative studies have documented the health benefits or consequences of living close to or far away from parks and recreation facilities. Indeed, recreation participation depends on the extent to which recreation resources are accessible. Walking and physical exercise were far lower in communities that are park poor and lacked some basic amenities (eg. paved trails) which facilitated these activities while it has been posited that higher obesity rates and other risk factors were more prevalent in communities where parks and recreation amenities were lacking (Hendee, 1969; Gorden-Larsen, et al., 2006; Scott, 2013)

\section{Park Patronage during Waiver Periods}

Registration fees may impact the ability of low-income residents to participate in public related sports programmes. An instance was cited in 2009 where an experiment was conducted in Gaithersburg, Maryland to see if a facilitated programme waiver increased programme participation. All children living in Gaithersburg had the option of simply checking a box stating that they were a resident of Gaithersburg and were requesting a waiver of registration fees, for most programmes the fee was $\$ 40$. Waivers were automatically granted without any required documentation. Generally, people who received waivers had high rates of participation in games and in recreational parks. Economic impacts on residents around amusement parks increases through the economic multiplier effects since a number of participants in recreational programmes were more likely to increase when waivers are introduced in parks (Low, 2005; Berk \& Moon, 2016; Berk, 2016; Ayitoliya, 2017).

\section{Safety Awareness in Public Parks}

Fear of crime is among the most frequently reported reasons why many poorer Americans did not greatly participate in leisure facilities near their neighbourhoods. Those who lived in poor neighbourhoods worried about crime and physical assault. 
In a study of why people did not use parks in Northeast Ohio, it came to the fore that over half of all low-income residents reported fear of crime being an inhibiting factor to their use of parks in the area. Safety in Rattray Park is ensured through the provision of security officers at the various sub-parks including the provision and maintenance of correct safety measures like refuse bins, non-slippery surfaces, and non-sharp edges in parks. The most effective way of achieving safety in parks and gardens is by ensuring efficient and strict enforcement of park regulations which technically are referred to as codes of conduct in park facilities (Scott, 2013, Cohen et al. 2016; KMA, 2017; Department of Parks and Gardens, 2017).

\section{METHODOLOGY}

\section{Study Area}

Kumasi is the second largest city in Ghana and the capital of the Ashanti Region. Kumasi used to be known as the Garden City of West Africa. This was because, during the colonial era, planning interventions in Kumasi were in the form of establishing green belts and recreational parks within the layouts of residential areas. Due to the undulating topography and numerous streams that transect Kumasi, the green belts and recreational parks were invariably situated along the major streams. Kumasi is also a noted nodal town linking most of the major towns in Ghana. The population of the metropolis is about 1,730,249 comprising 826,479 males and 903,770 females respectively (GSS, 2010). Figure 1 shows map of Kumasi within the context of the Ashanti Region and the country as a whole. 


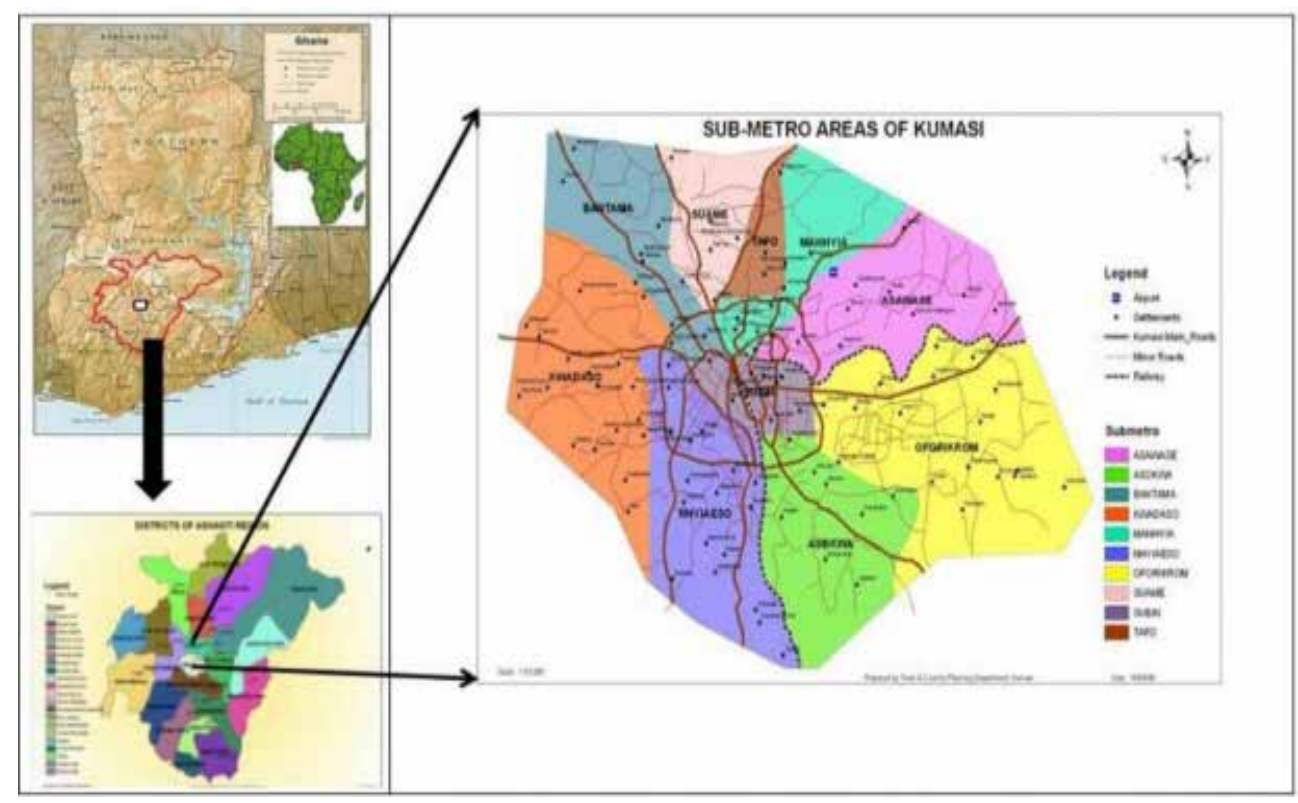

\section{Figure1: Location of Kumasi in rational and regional contexts.}

Source: Kumasi Metropolitan Assembly (2010).

The park has been named after a British man called Captain Robert Sutherland Rattray, who was a Scot but duty stationed in the then Gold Coast in the precolonial era now named Ghana. According to KMA Annual Report (2017), Rattray (1881-1938) was an early Africanist and student of Ashanti. He was one of the early writers on Oware, and on Ashanti gold weight. Rattray was born in India to Scottish parents. In 1906, he joined the Gold Coast Custom Service. He became the Assistant District Commissioner at Ejura in 1911. Learning local languages, he was appointed head of anthropological department of Asante in 1921. He retired in 1930 but met his untimely death while flying a glider in 1938. According to history, on one of his returns to Kumasi, Rattray unfortunately had a glider crash. However, he did not die immediately in the accident but the incident led to his death on 5 th May, 1938 in Oxfordshire. It is believed that the very location of the current Rattray Park in Kumasi city is the very spot of his accident, hence the name Rattray Park. The park recorded the highest visits from 1st July, 2015 - December 2015, after which the other peak periods were normally recorded in the months of November, December and first week of January due to the festivities celebrated within this season. Depending on the calendar of activities within the year, ending of March or beginning of April is considered another peak period due to the Easter festivities. 
The attendance is averagely good during public holidays. During week days, attendance is usually between 20 to 150 adults while the weekends would usually witness 150 to 250 adult visitors [children non-inclusive] (KMA, Annual Report, 2017). Major attractions in the park include the following: A lake and two dry fountains, a cafeteria currently non-operational, open car safari, walking safari, VIP guest room, lovers' benches sited under colourful avenue trees and hedges which provides a conducive atmosphere for relaxation, an ultra-modern lawn and colourful ornamental plants, providing hi-tech scenery and a panoramic view, a mini golf course sited in the south-western part of the park, children's park sited behind the golf course and historical statues of the past Ashanti kings as well as the statue of Captain Rattray which is sited at the main entrance to the park (See Plate 1 on Ariel view of Rattray Park in Kumasi).

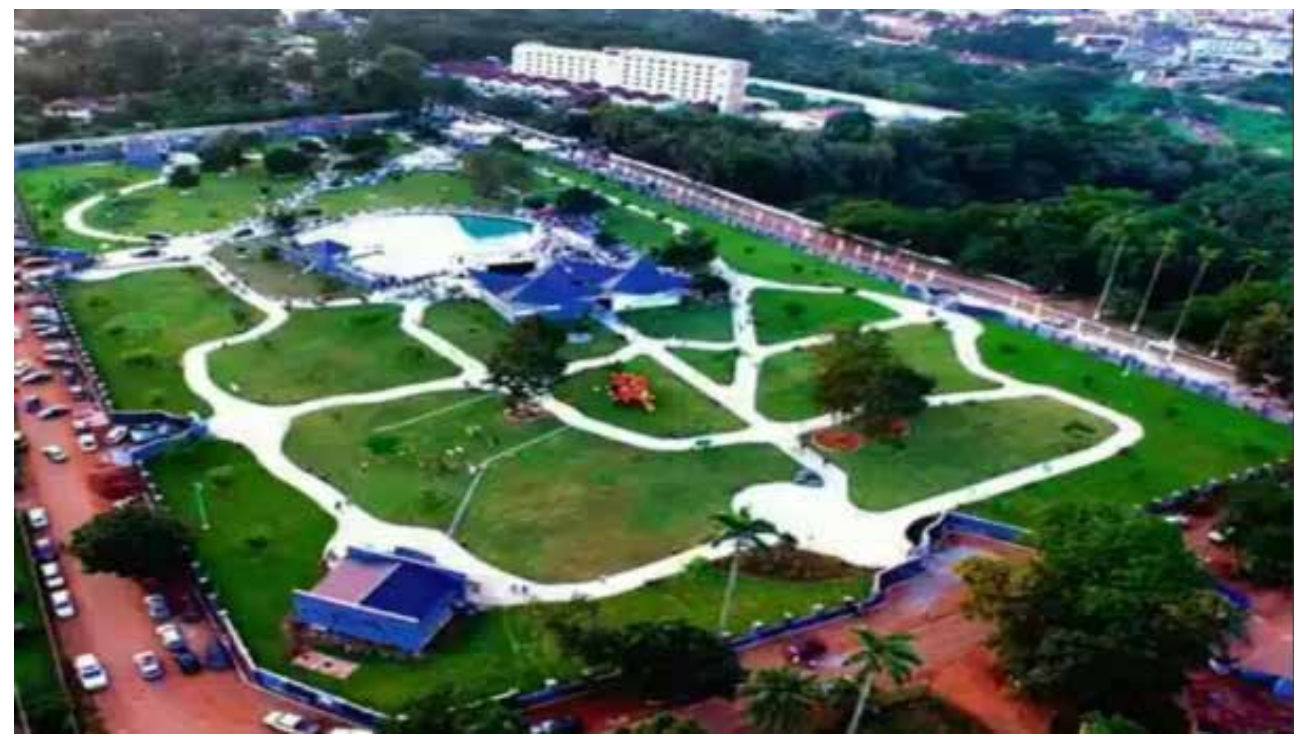

\section{Plate 1: Ariel view of Rattray Park in Kumasi}

Source: Kumasi Metropolitan Assembly (2017).

\section{Research Design}

The survey study method was preferred because it allowed the researchers to comprehend the case in general with regard to the study objectives. The collection of information from a sample of individuals and based on their responses to questions posed shall serve as the central theme of the survey method (Check \& Schutt, 2012). This method was preferred mainly because it dealt with a technically distinctive situation, relied on multiple sources of evidence and benefits from 
prior development of prepositions to guide data collection and analysis. Again, it is a single survey study strategy, which allowed the researchers to look at the existing situation especially when waivers were introduced in the recreational park. Moreover, it also helped to combine both quantitative and qualitative approaches to data collection that allowed the researchers to gain a rich mix of data for analysis and interpretation (Ponto, 2015).

The procedure this study adopted for data collection included the collection of both primary and secondary data which were obtained from the respondents in public institutions like the Departments of Parks and Gardens (Rattray inclusive) and from the Land Use and Spatial Planning Authority who had offices in the park. Presenters of some FM Radio stations and KMA officials were also contacted in the park. The main instrument for the primary data collection used for this study comprised structured questionnaires made up of both open-ended and close-ended questions. An integration of both interviews and questionnaires were employed to collect data from the various institutions which participate in the management of parks in Kumasi and such officials were met in their offices in the park where the interviews were granted.

From the data provided by the park officials on average attendance to the park by visitors during waivers, December 2017 was chosen as a conducive period because there were three days of waivers during the yuletide. This started on the 23rd of December to the 24th of December, 2017 and the final day of the year which was the 31st of December, 2017. Official statistics on tickets sold were, however, not revealed to the researchers as the accountant to the facility explained that it was unethical to divulge such information even though the team had tendered in a letter of introduction. On the other hand, a physical count by the research team pegged attendance for adults for the three days at 492, 500 and 508 respectively, excluding children. Averagely, it meant that about 500 revellers visited the park during the 2017 December waiver period. Based on this, $10 \%$ of the daily attendance was targeted upon which 50 respondents were contacted each day for the study, thus making a sample size of 150 . At the end of the survey it was however realised that 141 of the questionnaire were useful giving a response rate of $94 \%$. In addition to this, five radio presenters (their radio stations have always been involved in organising the waiver programmes from the onset and had continually been given the opportunity to advertise the waiver programmes). Similarly, these presenters were met at the park premises displaying their respective radio station tags and so were purposively selected for the IDI. Four officials of management of the park who 
agreed to grant us the interview and one staff from KMA duty-stationed at the park were all contacted through IDI at the facility.

Analysis was done for both quantitative and qualitative data. For qualitative data, information sourced was put into themes for the purpose of analysis. Data was thus sorted, coded and analysed. Tabulations were achieved via quantitative analysis techniques as data was processed using Microsoft Excel and Statistical Package for Service Solutions (SPSS). Descriptive statistics were employed to calculate the frequencies, means and percentages of the data obtained for the research. Further tests such as Pearson's Chi-Square tests (x2) was applied to assess two comparisons: homogeneity and independence (association) aimed at evaluating the categorical data on how likely it is that any observed difference in the sets arose by chance. The ARIMA (TIME SERIES) model was also adopted to detect seasonality and trend analysis of visitation to the park.

\section{RESULTS AND DISCUSSION}

The demographic characteristics of respondents are presented under themes such as gender, age, educational qualification, family situation, occupation and net monthly income and place of stay. Table 1 shows results collated and analysed with regard to the aforementioned which were cross-tabulated with their views on the patronage of the park since its inception. Demographic characterisation is an important analytical tool used for analysing recreationists' related activities. The study disclosed that about $25 \%$ of visitors to the park were low income earners with approximate net-monthly income of less than Ghc200.o (about 35USD). This poor income situation according to respondents inhibited their regular utilisation of the park and further stated they patronised the park during fee waivers to entertain themselves. The study revealed even those who had a salary range of between GHc 600-1000 considered themselves low income earners and confirmed their take home (net pay) was really meagre. Respondents complained that aside from the entry fee of Ghc1o per adult, all other series of activities in the park such as going on the pony ride and swimming were all paid for. In an interview with a park management official, he offered an explanation:

You see if one must get entertained to his satisfaction you need about GHc50.o to get engaged actively and this even excludes cost of snacks or a lunch pack. When you consider all this, the low income earners will see it a luxury and so waivers offer an opportunity to enable such people to come here for recreation especially when they 
can substitute the entrance fee for engagement in an activity in the park. This is what makes a fee-waiver relevant to the low income class of people in the metropolis [33-year-old Respondent: IDI, December 2017].

It came to the fore that $41 \%$ of the metro residents who visited the park were unemployed. This also gives a clue that even non-income earners seized fee-waiver opportunities to access the park. This category of respondents also indicated the park was well patronised during fee waiver sessions. Never married respondents (53\%) took an advantage to visit Rattray Park with many reiterating the park was better patronised during waivers while married with kids (35\%) who also visited possibly at the behest of their kids considering that kiddie related activities therein which served as a pull factor. The results as also presented in Table 1 showed female respondents being in the majority (62\%) and this compares well with studies by Adam (2015) in his study on backpackers' risk perceptions and risk reduction strategies in Ghana where female respondents were in the majority and that of Moore et al. (2008) where female respondents dominated a study on availability of recreational resources in minority and low socio-economic status areas. It was observed that children under 15 years of age were about three times the number of adults in the park. The most plausible reason being that most kids came with their mothers to the recreation grounds, hence the high female participation. 
Table 1: Cross-tabulation of demographic characteristics of respondents with their views on park patronage during fee waivers

\begin{tabular}{|c|c|c|c|c|c|c|c|}
\hline \multirow{2}{*}{\multicolumn{2}{|c|}{$\begin{array}{l}\text { Demographic Characteristics } \\
\text { of Respondents }\end{array}$}} & \multicolumn{6}{|c|}{ Views on Park Patronage } \\
\hline & & VP & SP & P & NP & $x^{2}$ & Total \\
\hline $\begin{array}{l}\text { Approximate } \\
\text { net monthly } \\
\text { income } \\
\text { Total }\end{array}$ & $\begin{array}{l}<\text { GHS } 200 \\
\text { GHS } 200-600 \\
\text { GHS } 600-1000 \\
>\text { GHS } 1000\end{array}$ & $\begin{array}{c}17 \\
7 \\
18 \\
21 \\
63\end{array}$ & $\begin{array}{c}8 \\
7 \\
4 \\
16 \\
35\end{array}$ & $\begin{array}{c}10 \\
5 \\
1 \\
9 \\
25\end{array}$ & $\begin{array}{c}1 \\
1 \\
6 \\
10 \\
18\end{array}$ & 0.034 & $\begin{array}{c}36 \\
20 \\
29 \\
56 \\
141\end{array}$ \\
\hline Occupation & $\begin{array}{l}\text { Teacher } \\
\text { Nurse } \\
\text { Civil Servant } \\
\text { Trader } \\
\text { Unemployed }\end{array}$ & $\begin{array}{c}13 \\
5 \\
5 \\
17 \\
23 \\
63 \\
\end{array}$ & $\begin{array}{c}7 \\
2 \\
4 \\
4 \\
18 \\
35 \\
\end{array}$ & $\begin{array}{c}3 \\
5 \\
1 \\
5 \\
11 \\
25\end{array}$ & $\begin{array}{c}5 \\
2 \\
0 \\
5 \\
8 \\
18\end{array}$ & 0.463 & $\begin{array}{c}28 \\
14 \\
10 \\
31 \\
58 \\
141 \\
\end{array}$ \\
\hline $\begin{array}{l}\text { Family } \\
\text { situation }\end{array}$ & $\begin{array}{l}\text { Never married } \\
\text { Married } \\
\text { Married with kids } \\
\text { Divorced } \\
\text { Widowed/ widower }\end{array}$ & $\begin{array}{c}38 \\
5 \\
21 \\
0 \\
1 \\
63 \\
\end{array}$ & $\begin{array}{c}19 \\
3 \\
13 \\
- \\
- \\
35\end{array}$ & $\begin{array}{l}11 \\
4 \\
9 \\
1 \\
- \\
25\end{array}$ & $\begin{array}{c}8 \\
3 \\
6 \\
1 \\
- \\
18 \\
\end{array}$ & 0.720 & $\begin{array}{c}74 \\
15 \\
49 \\
2 \\
1 \\
141 \\
\end{array}$ \\
\hline $\begin{array}{l}\text { Educational } \\
\text { status } \\
\text { Total }\end{array}$ & $\begin{array}{l}\text { Non - formal } \\
\text { Basic education } \\
\text { SSS/SHS } \\
\text { Tertiary level }\end{array}$ & $\begin{array}{c}- \\
2 \\
18 \\
43 \\
63\end{array}$ & $\begin{array}{l}- \\
- \\
11 \\
24 \\
35\end{array}$ & $\begin{array}{c}- \\
6 \\
4 \\
15 \\
25\end{array}$ & $\begin{array}{l}- \\
1 \\
- \\
17 \\
18\end{array}$ & 0.938 & $\begin{array}{c}- \\
9 \\
33 \\
99 \\
141\end{array}$ \\
\hline Total & $\begin{array}{l}<18 \text { years } \\
18-28 \text { years } \\
29-38 \text { years } \\
>38 \text { years }\end{array}$ & $\begin{array}{c}7 \\
38 \\
14 \\
4 \\
63\end{array}$ & $\begin{array}{c}2 \\
17 \\
14 \\
2 \\
35\end{array}$ & $\begin{array}{c}6 \\
13 \\
6 \\
- \\
25\end{array}$ & $\begin{array}{c}1 \\
6 \\
10 \\
1\end{array}$ & 0.091 & $\begin{array}{c}16 \\
74 \\
44 \\
7 \\
141\end{array}$ \\
\hline $\begin{array}{l}\text { Place of stay } \\
\text { Total }\end{array}$ & $\begin{array}{l}\text { Kumasi } \\
\text { Outside Kumasi }\end{array}$ & $\begin{array}{c}60 \\
3 \\
63 \\
\end{array}$ & $\begin{array}{c}33 \\
2 \\
35\end{array}$ & $\begin{array}{c}25 \\
- \\
25\end{array}$ & $\begin{array}{c}17 \\
1 \\
18\end{array}$ & 0.252 & $\begin{array}{c}135 \\
6 \\
141\end{array}$ \\
\hline $\begin{array}{l}\text { Gender } \\
\text { Total }\end{array}$ & $\begin{array}{l}\text { Male } \\
\text { Female }\end{array}$ & $\begin{array}{l}26 \\
37 \\
63\end{array}$ & $\begin{array}{l}13 \\
22 \\
35\end{array}$ & $\begin{array}{c}7 \\
18 \\
25\end{array}$ & $\begin{array}{c}7 \\
11 \\
18\end{array}$ & 0.611 & $\begin{array}{r}53 \\
88 \\
141\end{array}$ \\
\hline
\end{tabular}

Source: Field Data, 2018.

$\mathrm{VP}=$ Very well patronised, $\mathrm{SP}=$ Somewhat patronised, $\mathrm{P}=$ Patronised, $\mathrm{NP}=$ Not well patronised. 
Further observations disclosed a more than $51 \%$ of the participants visiting the park were in the 'empty nest' stage (never married/newly married but yet to begin child bearing or children had fully grown and left home to begin their own families) giving the impression that the absence of children may also imply more leisure time, hence an opportunity to visit parks. About 70\% percent of these waiverperiod-park-goers had attained tertiary education status and this possibly hinted on the graduate unemployment situations as noted earlier in the discussion.

\section{Basis for Introduction of Waivers in Rattray Park}

Interview sessions with park officials and media partners revealed that the basis for introduction of waivers in the park were to increase park accessibility to the disadvantaged (poor urban dwellers), and also to aid internships including research and academic work. More so, this was done especially to enhance park benefits to revellers such as in the areas of psychological, social and health through entertainment and physical activities. Some responses gathered from the scheduled interviews are noted in the ensuing narratives: "Waivers are basically introduced to increase park returns, to make park accessible to many who ordinarily due to financial pressures cannot afford to come. Waivers are also introduced to aid research and academic work" (IDI, 43-year-old KMA official, January 1, 2018).

The radio presenters who are often tasked with the duty of giving prominence to fee waivers through the airwaves said:

The waiver programmes are organised in the park as joint partnership of the media and KMA. It is done for entertainment and recreation. Advertisements are done through radio broadcasts. We also make use of the services of celebrities or comedians in our adverts. We organise the waiver programme to bring in the masses who due to financial burdens may not have come (IDI, 2 Radio presenters of BOSS 93.7 FM: LUV 99.5 FM, Kumasi, December 26, 2017).

Another view gathered from park management with regard to the introduction of waivers was stated:

We offer waivers so that the underprivileged in society can also seize such opportunities to engage in some recreational pursuits. We also offer waivers to quite a lot of students and researchers to undertake research studies in the park. We think that the 
publication of such results can publicise the facility better and we usually encourage the researchers to communicate their findings to us (IDI, Park Management, January 1, 2018).

This latter reportage seems to be consistent with the findings of a study by Lathrop Park and Recreation (2015) and that of the US National Park Service (2018) which both reportedly stated that the basis for issuing waivers in parks were basically to enable students and other researchers to undertake research, internships including meeting their recreation needs and other academic related activities.

\section{Barriers to Park Use by the Urban Poor}

Responses analysed from visitors and park management indicated different categories of setbacks to the use of the park. Evidence contained in figure 3 portray about $70 \%$ of visitors' rated financial barriers as a key hindrance to access. Indeed, many Ghanaians do not take formal recreational activities seriously as in visiting parks which is often seen to be a privilege of the well-to-do in society and those with exposure to foreign lifestyles. Thus, price hikes will often be noted as a hindrance by low income earners to visiting parks for recreational purposes. This study emphasises that the most prevailing economic barriers to utilising Rattray Park for recreation were high entry fees, high cost of services provided in the park (cafeteria services, face painting and entertainment services) and even high cost of transportation to the park. Whilst respondents complained of the high cost related issues, they also bemoaned the paucity of recreational activities in the park necessary to engaging them all day long and called for the introduction of more recreational activities at affordable cost. Such difficulties "entrapping" the poor and their recreational needs is vividly expressed by Berk (2016) and Massey (2007), to the effect that the poor do not have the recreation rooms, landscaped backyards, automobiles, recreation vehicles, seasonal homes and other resources and amenities that enhance the recreation environment. On views on barriers to the use of the park, opinions expressed centred on political related tensions and inadequacy of attractions within the park which registered about $66 \%$ and $75 \%$ ratings respectively (see Figure 2). 


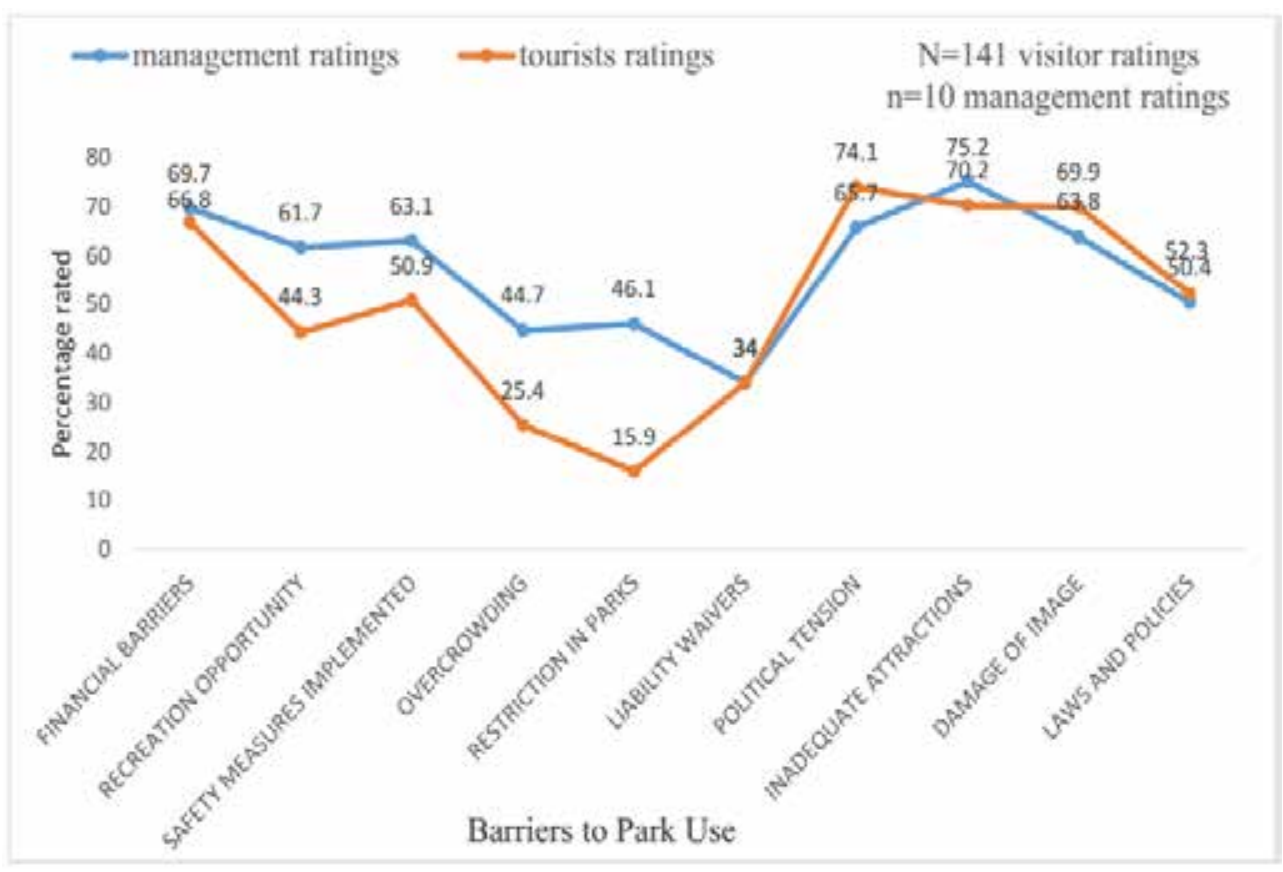

Figure 2: Views on barriers to use of park by visitors and management

Source: Field Data, 2018.

An IDI from management pertaining to political challenges revealed:

Rattray Park was well patronised initially after it was inaugurated on the 19th of June, 2015 and the subsequent commencement of operations in September, 2015. However, the level of patronage in the park decreased drastically during the period when there was change in government in January, 2017, stemming from fear of "party in power boys" taking over operations in the park as witnessed in other similar government recreational establishments (IDI, December 2017).

The political reasons raised by management and purported to be a barrier to park use seems to agree with the findings of Henderson (1997), who stated that a major challenge that park and recreation leaders including other recreation related agencies are often "confronted" with is to seek to create recreation opportunities for the poor which was political in nature. 


\section{Patronage Levels during Waivers in Rattray Park}

The study indicated the park was patronised more during the introduction of waiver programmes and to this, $44 \%$ of respondents alluded. Close to $26 \%$ of respondents also alluded to the facility being well patronised during public holidays while weekends and week days came next with $18 \%$ and $13 \%$ of respondents affirming respectively. From the time series graph (see Figure 4), important trends identified in the park where that the number of tourists increased across certain periods, thus the trend was: waiver periods $>$ holiday periods $>$ weekends $>$ weekdays while general increases were also noted during peak seasons, notably Easter festivity season, traditional festival celebrations in Kumasi and days declared as national holidays by the state. The extent of patronage is illustrated in the ARIMA (Time Series) model noted in Figure 3.

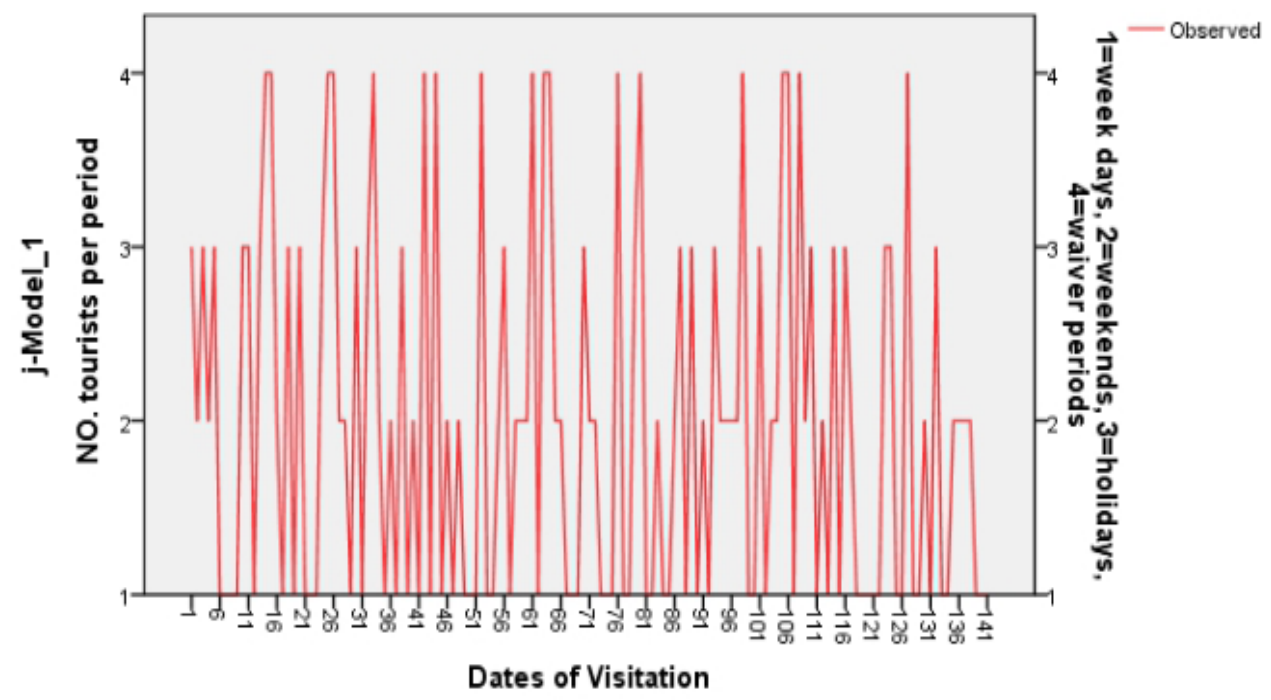

\section{Figure 3: Time series plot of visitation in Rattray Park}

Source: Field Data, 2018.

This finding bears semblance to the findings of a demonstration project conducted in Gaithersburg, by Berk and Moon (2016) which revealed that people who received waivers had high rates of participation in games and other exercises related to recreational parks for its associated benefits. Close to $44 \%$ of respondents indicated they were aware the waiver programmes are organised by the park management (KMA) in partnership with the media broadcasting houses (radio 
stations). Respondents also indicated their source of information about waivers was the partner radio stations in the metropolis and massing up of people in the park had several economic advances even to attendees. This supports the view of Low (2005), who stated that the implication as waivers leading to a significant improvement regarding attendance at parks and a corresponding high improvement in the economic returns from the park to neighbourhoods within. Similarly it also supports the literature as espoused by Department of Leisure, Family and Recreation, Manchester Recreation Division, (2020), that other associated advantages in relation to increased visits to parks include increased social relations and contacts in addition to health benefits that emanate from introduction of waivers. From the asymptotic significance (2-sided) the Pearson Chi-Square $\mathrm{P}$-value $(\mathrm{P}=0.034)$ when income status of respondents was cross tabulated with park patronage levels at degree of freedom $(\mathrm{df}=3)$ the Pearson Chi - Square value for income which has a direct positive correlation with fee waiver is less than 0.05 $(\mathrm{P}<0.05)$. This by implication means that a significant increase in attendance was attained when waivers are introduced in the park.

\section{Safety Awareness in the Park}

The study brought to the fore the awareness levels of visitors on issues concerning safety in the park. Revellers indicated the implication of waivers and safety issues were explained to them during debriefing sessions at the park's entrance. Table 2 indicates there was no statistically significant relationship between gender and safety awareness in the park with Pearson's Chi-Square Value p (0.206)>0.05 at degree of freedom (df) of 1. Although researchers like Crompton, et al. (2015) have postulated demographic factors such as gender are predictors of sense of safety in natural settings, findings from this study proved contrary. Results from this study noted a very weak relationship between gender and safety awareness levels in the park and this however seems to concur with the findings of Poku (2016) where gender of respondents was not a significant predictor of tourists' safety perceptions at Kakum National Park in the Central Region of Ghana. Scott (2013) in a study of why people do not use parks in Northeast Ohio, found that over half of all lowincome residents reported fear of crime gaining prominence in limiting their use of parks in the area. 
Table 2: Relationship between gender and safety awareness level in Rattray Park

\begin{tabular}{|c|c|c|c|c|c|c|c|c|}
\hline & \multicolumn{5}{|c|}{ Safety awareness levels in the park } & \multirow[b]{2}{*}{ Total } & \multirow{2}{*}{$\begin{array}{c}\mathrm{X}^{2} \\
(\mathrm{df}=\mathbf{1})\end{array}$} \\
\hline & & $\begin{array}{l}\text { very } \\
\text { low }\end{array}$ & low & neutral & high & $\begin{array}{l}\text { very } \\
\text { high }\end{array}$ & & \\
\hline \multirow[t]{2}{*}{ Gender } & Count & o & 1 & o & o & o & 1 & \multirow{8}{*}{0.206} \\
\hline & $\%$ & 0.0 & 0.7 & 0.0 & 0.0 & 0.0 & 0.7 & \\
\hline \multirow[t]{2}{*}{ Male } & Count & 6 & 3 & 14 & 10 & 19 & 52 & \\
\hline & $\%$ & 4.3 & 2.1 & 9.9 & 7.1 & 13.5 & 36.9 & \\
\hline \multirow[t]{2}{*}{ female } & Count & 9 & 9 & 22 & 19 & 29 & 88 & \\
\hline & $\%$ & 6.4 & 6.4 & 15.6 & 13.5 & 20.6 & 62.4 & \\
\hline \multirow[t]{2}{*}{ Total } & Count & 15 & 13 & 36 & 29 & 48 & 141 & \\
\hline & $\%$ & 10.6 & 9.2 & $25 \cdot 5$ & 20.6 & 34.0 & 100 & \\
\hline
\end{tabular}

Source: Field Data, 2018.

The Department of Parks and Gardens (2017) reported the most effective way of achieving safety in parks and gardens which is to ensure efficient and strict enforcement of park regulations technically referred to as a park's code of conduct. It is therefore evident from the study that, safety awareness levels in the park from the visitor perspective is significantly high. This assertion can be attributed to adequate precautionary measures taken by visitors before and during their visit to the park and it further implied a higher likelihood of recording low loses, damages and injuries during the use and enjoyment of the park and its services during waiver programmes.

\section{CONCLUSION}

The study brought to the fore the fact that the introduction of fee waivers in particular boosted attendance to Rattray Park as many low income residents were the beneficiaries of this package. The Chi-square statistic proved there was indeed a significant relation between introduction of fee waivers and increased patronage of the park by low income earners. Barriers to park use brought forth by the urban poor were noted to be financial reflective in the instances of high entrance fees to the facility and also the fact that every major activity in the park was paid for. Key stakeholders responsible for the fee and liability waiver programmes in Rattray Park were also brought to the fore in the findings and they included the KMA, park management and some radio stations notably LUV FM and BOSS FM. The radio stations created the awareness through publicity in their broadcasts. High attendance to the park was registered during national holidays especially during the 
Christmas and New Year festivity season, the weekends with a few only attending during weekdays. Revellers were made aware of the implications of introducing liability waivers and so in order to effect safety awareness issues in the park by management, the park's codes of conduct were strictly adhered to, as visitors were given intensive instructions on the rules and regulations and they made conscious efforts to comply.

\section{RECOMMENDATIONS}

More recreation activities need to be introduced by the KMA and management and to some extent, a number of such could be instituted for free or at giveaway prices so that the "common masses" even after paying entry fees could enjoy a number of activities for free or at relatively subsidised cost within the park. The current practice whereby every activity engaged in is paid for does not augur well for the full engagement by low income earners. This would motivate others to not only wait for waivers but to take opportunity during other public holidays to patronise the facility.

On policy implications, the KMA can be commended for being a pacesetter through initiating a recreational facility for urban dwellers. It will therefore be necessary for the Ministry of Local Government and Rural Development to pave the way for some form of legislation aimed at ensuring that regional coordinating councils in Ghana including the MMDAs emulate such worthy examples of establishing recreational parks for their residents to also gain similar opportunities for their own recreational needs for a healthier life.

\section{REFERENCES}

Adam, I. (2015). Backmarkers' risks perceptions and risk reduction strategies in Ghana. Tourism Management, 49, 99-108.

Ayitoliya, G. (2017). The situation of managing parks and gardens in Ghana. Valuation of Rattray Park-Kumasi City. KNUST Press.

Berk, M., \& Moon, M. M. (2016). Effects of a facilitated fee waiver programme on participation of in youth sports programmes. Journal of Park and Recreation Administration, 34(3). DOI: https://doi.org/10.18666/JPRA-2016-V34-I3-6434.

Berk, M. (2016). The impacts of fee waivers on city youth sports participation. Available at https://activelivingresearch.org/blog/2016/11/impact-fee-waivers-cityyouth-sports participation. Accessed 2oth July, 2018. 
Check J., \& Schutt R. K. (2012). Survey research. In: R. Check \& Schutt.K. (ed). Research methods in education. Thousand Oaks, CA, Sage Publications.

Chubb, M. \& Chubb, H. R. (1981). One third of our time. New York: John Wiley and Sons.

Cohen, D. A., Han, B., Kathryn P., Derose, K. P., Williamson, S., Terry-Marsh, T., Raaen, L., \& McKenzie, T.L. (2016). The paradox of parks in low-income areas: Park use and perceived threats. Environmental Behaviour 48(1), 230-245.

Cranz, G. (1982). The politics of park design. The MIT Press.

Crompton, J.L, Jeong, J. Y., \& Dudensing, R. M. (2015). Sources of variation in economic impact multipliers. Journal of Travel Research, 1-14.

Daniels, G. \& Schur, M. (2015). Parks and recreation. The absurd antics of an Indiana town's public officials as they pursue sundry projects to make their city a better place. $\mathrm{ABC}$ Comedy by Chris Pratt Bloopers.

Das,D.,\&Honiball,J.(2016).Evaluationofaccessibilitychallengesofpublicparksinresidential areas of South African cities. A case study of Bloemfontein city. Available at https:// pdfs.semanticscholar.org/96a2/de1aoeogcoacc1c86e4a2f9684ob6af1e5d3. pdf. Accessed 25th August, 2020.

Department of Parks and Gardens. (2017). City parks and recreation administration. The Garden City. Accra.

Department of Leisure, Family and Recreation, Manchester Recreation Division (2020). Parks and recreation. The benefits are endless. Available at recreation1. townofmanchester.org. Accessed 2oth January, 2020.

Denise, L. Evans, J. D., \& William, O. (2007). Waivers-The real estate encyclopedia. The McGraw-Hill Companies Inc.

Fishkin, J. (1983). Justice, equal opportunity and the family. Yale University Press.

Ghana Statistical Service (2010). Population and housing census. Accra, GSS.

Gordon-Larsen, P., Nelson, M.C., Page, P., \& Popkin, B.M. (2006). Inequality in the built environment underlies key health disparities in physical activity and obesity. Pediatrics, 117(2), 417-424.

Hendee, J. C. (1969). Rural-urban differences reflected in outdoor recreation participation. Journal of Leisure Research, 1(4), 333-341.

Henderson, K. A. (1997). A critique of constraints theory: A response. Journal of Leisure Research, 29, 453-457.

Kumasi Metropolitan Assembly (2010). Kumasi development plan (2010-2013), KMA. 
Kumasi Metropolitan Assembly (2017). Annual report on development plan of Kumasi. KMA press.

Lathrop Parks and Recreation (2015). Guidelines for fee waivers for the City of Lathrop. City of Lathrop Press.

Low, M. J. (2005). It's the end of the world as we know it ... and I feel fine: The new rules for drafting liability waivers in Arizona. FORC Journal, 16(3), 10-13.

Makufwe, W. M. (2014). Prospects and challenges of greening the Kumasi Metropolis. A Masters' Thesis submitted to the Department of Planning, Kwame Nkrumah University of Science and Technology, Kumasi.

Massey, D. S. (2007). Categorically unequal: The American stratification system. The Russell Sage Foundation.

Moore. L. V., Roux, A. D., Evenson, K. R., McGinn, A., \& Brines, S. J. (2008). Availability of recreational resources in minority and low socio-economic status area. American Journal of Preventive Medicine 34(1), 16-22.

National Park Service (2018). Yellowstone National Park Protection Act (1872). Available at https://www.nps.gov/yell/learn/management/ Yellowstoneprotectionact1872.htm. Accessed 3oth December 2018.

National Park Service (2018). Grand Canyon National Park Arizona. Available at https://www.nps.gov/grca/planyourvisit/educational-fee-waiver.htm. Accessed 12th August 2018.

Poku, G. (2016). Safety and security of tourists at the Kakum National Park, Ghana. Unpublished Master of Philosophy Thesis submitted to the Department of Hospitality and Tourism Management, University of Cape Coast, Ghana.

Ponto, J. (2015). Understanding and evaluating survey research. Journal of the advance practitioner in oncology, 6(2), 168-171.

Safaris Africana (2018). The largest national parks in the world. Available at: https:// safarisafricana.com/largest-national-parks-in-the-world/. Accessed 2oth December 2018.

Scott, D. (1997). The formative nature of conducting research for a Metropolitan Park District. Applied Behavioural Science Review, 4, 25-39.

Scott, D. (2013). Economic inequality, poverty and park recreation delivery. Journal of park and recreation administration, 31(4), 1-11.

Sibeko, S. D. (2007). The provision and utilisation of recreation facilities for the youth at Ngwelezane Township, KwaZulu-Natal. A dissertation of limited scope submitted to Centre for Recreation and Tourism at the University of Zululand. 
Siler, M. (2011). Liability waivers-busting some common myths. Journal Federation of Regulatory Council, 23-34. Spon Press.

Tilly, C. (1999). Durable inequality. University of California Press.

Weber, M. (1978). Economy and society. University of California Press.

Younger, L. (2008). The city of Alexandria recreation, parks and cultural activities. Strategic Master Plan. Available at file://C:/Users/User/Downloads/ StrategicMasterPlan.pdf. Accessed, 25th August 2020. 